\section{International Scientific Journal Theoretical \& Applied Science}

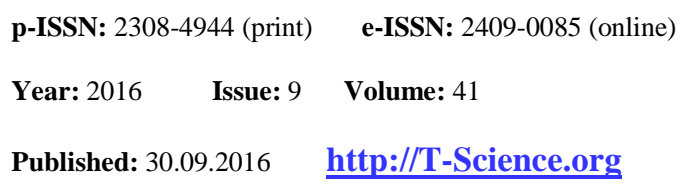

SECTION 31. Economic research, finance, innovation, risk management.
A.Sh.Kupeshev

Doctor of economical science, professor, Kazakh Engineering and Pedagogical University of Nations Friendship

M.Eskara

Doctor of agricultural science, professor, Kazakh Engineering and Pedagogical University of Nations Friendship

Aigul Kuanyshevna Kupesheva Candidate of economical science Chief of department of Kazakh Engineering and Pedagogical University of Nations Friendship

\section{Ersultan Zhomartovich Shalkhar} Muster student of Kazakh Engineering and Pedagogical University of Nations Friendship

Nurlan Muhtarovich Batyrbaev Candidate of law science, professor Vice president of International Kazakh-

Turkish University after H.A.Yessevi

Erkin Shazhievich Dusipov

Doctor of law science, professor Zhetysu state University after I.Zhansugurov

Yernar Sailaubekovich Shalkharov

Master of law, economics, bachelor of biology Corresponding member of Theoretical and Applied Science Academy. General director of BeinAgroIndustries LTD yernar_shalkharov@bk.ru

\title{
THEORETICAL ASPECTS OF THE HUMANIZATION CONCEPT AND ITS POSITIONING IN SPACE IN COMPLIANCE WITH THE NEW RATE OF CRIMINAL POLICY OF THE REPUBLIC OF KAZAKHSTAN
}

Abstract: Today the Republic of Kazakhstan is dynamically developing state on the world scene in the conditions of market economy as the constitutional democratic state. Therefore, all reforms undertaken in the state are closely connected with upgrade of legal institutions towards democratization of society. As one of such institutes authors of this article consider humanization policy in the Republic of Kazakhstan, and also questions of its adaptation to the Kazakhstan society having certain specifics.

Key words: Kazakhstan, world scene, policy.

Language: English

Citation: Kupeshev AS, Eskara M, Kupesheva AK, Shalkhar EZ, Batyrbaev NM, Dusipov ES, Shalkharov YS (2016) THEORETICAL ASPECTS OF THE HUMANIZATION CONCEPT AND ITS POSITIONING IN SPACE IN COMPLIANCE WITH THE NEW RATE OF CRIMINAL POLICY OF THE REPUBLIC OF KAZAKHSTAN. ISJ Theoretical \& Applied Science, 09 (41): 159-161.

Soi: http://s-o-i.org/1.1/TAS-09-41-27 Doi: crossef http://dx.doi.org/10.15863/TAS.2016.09.41.27

\section{Introduction}

Nowadays the Republic of Kazakhstan is one of 50 countries with the highest level of world competitiveness. This Republic provision positions first of all as the constitutional democratic state with strong system of functioning of internal mechanisms. 
Enhanced industrial, economic, cultural and including legal mechanisms which are based, first of all, on state policy rate (1). The penal legislation of the Republic of Kazakhstan also is stage of new stage transition which humanization main vector. Also important to understand that any punishment, first of all, is directed to understanding made offense crime and public danger of the act. It is also about humanization (2).

\section{Materials and Methods}

Certainly proceeding from the principles of economic prosperity it is possible to assume pragmatically that the policy of a humanization is necessary for the state as net logically many convicts for small offenses serve sentence at the expense of means of the state, to be exact taxpayers, meanwhile as questions of social security still remain disputable and questions of financing of many objects depend only from means of representatives of a business sector (3). In addition, as fairly noticed in the researches Cara C. MacInnis, Mary H. MacLean, Gordon Hodson concerning questions of political conflict between conservatives and liberals based on a disputable precedent on restriction of levels and conditions of abortions in the state in 2014 "Humanization is the most fair direction in departure of punishments by courts which has the best result, for society, and for state in general" (4).

Of the one part the matter really is the adequate decision in the situation which developed in the state, the main problem in any state was always the question of overpopulation of detention places (5). So in the following work researchers from the Arizonian State University, USA Călin Scripcaru, Simona Irina Damian, Ştefan Antonio Sandu, Beatrice Ioan stated following results with which in compliance in many countries various decisions were made, beginning from release of security prisoners, continuing by shortening of term because of good behavior and finishing with amnesty, having rather wide contingent adapted one number more if and spent the mass of public funds on implementations of various directions on socialization and rehabilitation of prisoners in the first five years of life after serving sentence for non-admission of repetitions of these crimes which almost didn't reduce crime rate in the region, including social security, an insurance and unemployment benefits in case of problems with employment as health workers, as a rule, lose the license for life because of a criminal record, meanwhile as in many medical organizations shortage of personnel resources reaches catastrophic limits and that is more urgent problem, the condemned health workers serve the punishment sentences together with other criminals which made different types of intentional crimes with causing heavy harm to health and even death (6). Transfer of criminal offenses category small weight to the administrative offenses category of with a levied penalty and the corresponding penalty fee for nonexecution of requirements of state bodies considerably will increase the state treasury by means of collection of these penalties regionally. In addition this policy gives prospect for development to many financial organizations as for example organizations performing collection types of activity where violators would obtain loans from the organization necessary for obligation fulfillment before state bodies of internal affairs and those organizations would expand the client base without being limited only in bank sphere (7). However, this economic progress in the state will surely serve as reverse side of negative effect at internally social and cultural levels that in turn will break balance among the population of the Republic of Kazakhstan as minor offenses like hooliganism, vandalism, causing small and average harm to health, frauds, thefts and rapes will begin many physical persons for which in the principle won't constitute work to make on a pocket socially dangerous the acts which entailed the criminal consequences made with a felonious intent, especially with that accounting that for this offense it will be possible just to pay a penalty to the state treasury and obligations to the state will be fulfilled (8).

Thus hypothetically can the number of recidivists will increase that in principle exclude any logic of policy correctness. Therefore, this factor directly influences the legal culture level in society. Many socially dangerous acts will accept nature of the transaction between the physical person which made offense and the state whose legal relationship are regulated only in penalties namely in the currency relations. On the one part it can positively influence society as based on increase in administrative penalties up to the sizes higher than ten sizes of minimum wage on these or those crimes much will be just too expensive to commit crimes, as is achievement of main goal stabilization of law level of and order in the state, of other part this result can have and reverse side of which sharp stratification of society on material prosperity is result.

For segments of the privileged population this concept can grant the right by nearly force to influence external factors that, somehow, is close to corruption in more legalized type. However we should consider in details available standard elements in the civil legislation of the Republic of Kazakhstan as this legal relationship directly pass under jurisdiction of the civil code of the Republic of Kazakhstan.

Thus, the side between the administrative legislation, the criminal legislation and the civil legislation is significantly washed away that in turn leads to loss of validity of many provisions, creates an imbalance in hierarchy of the legislation and owing to the instability to maneuver in legislative 


\begin{tabular}{|c|c|c|c|c|c|c|}
\hline Impact Factor: & $\begin{array}{l}\text { ISRA (India) } \\
\text { ISI (Dubai, UAE } \\
\text { GIF (Australia) } \\
\text { JIF }\end{array}$ & $\begin{array}{l}=1.344 \\
=0.829 \\
=0.564 \\
=1.500\end{array}$ & $\begin{array}{l}\text { SIS (USA) } \\
\text { PИНЦ (Russia } \\
\text { ESJI (KZ) } \\
\text { SJIF (Morocco }\end{array}$ & $\begin{array}{l}=0.912 \\
=0.234 \\
=1.042 \\
=2.031\end{array}$ & $\begin{array}{l}\text { ICV (Poland) } \\
\text { PIF (India) } \\
\text { IBI (India) }\end{array}$ & $\begin{array}{l}=6.630 \\
=1.940 \\
=4.260\end{array}$ \\
\hline
\end{tabular}

space will increase the level of legal nihilism in society that in turn extremely negatively affects on civil society development. The principle of democracy at this deal loses force automatically. However the humanization concept can become a push in development of the criminal legislation under some circumstances where the institute of a recurrence of socially dangerous offenses will be more carefully developed. At due studying of recurrence system it is possible to assume fairly that anticipation by the violator of more serious consequences if the administrative penalty can influence directly of individual legal education level and have really educational character which is supposed as main objective of punishment which in turn stops commission of socially dangerous acts by other persons that is the second purpose of institute of punishments which it is summarized increase law and order level in society it is main goal of criminal policy of the Republic of Kazakhstan.

\section{Conclusion}

Summing up the results, it will be reasonable to assume that the humanization is simplification of many minor offenses regulated by the administrative legislation of the Republic of Kazakhstan. However it is impossible to transfer responsibility from penal legislation limits as at internally national level this policy can lead to irreversible consequences completely. In case of all this should to note that during forming policy of penal legislation humanization more accurate emphasis needs to be placed on institute of recurrence. The recurrence is crucial element in humanization policy drawing distinction between law and order and chaos.

\section{Background.}

For a whole competent it is actual to notice that all issues in articles were formulated from the surveys of BeinAgroIndustries LTD. Also, it is important to mention together work of two university staff: Kazakh Engineering and Pedagogical University of Nations Friendship and International Kazakh-Turkish University after Khoga Akhmet Yassavi. In case of novelty, p.t.value the main author is the last in the list of authors.

\section{References:}

1. Cara C. MacInnis, Mary H. MacLean, Gordon Hodson (2014) Does "humanization" of the preborn explain why conservatives (vs. liberals) oppose abortion? Original Research Article Personality and Individual Differences, Volume 59, March 2014, Pages 77-82.

2. Roger Clarke, Lyria Bennett Moses (2014) The regulation of civilian drones' impacts on public safety Original Research Article Computer Law \& Security Review, Volume 30, Issue 3, June 2014, Pages 263-285

3. (2009) The decree of the President of the Republic of Kazakhstan from 24 August, 2009 No. 858 "About the Concept of legal policy of the Republic of Kazakhstan for the period from 2010 to $2020 " / /$ the Kazakhstan truth. - 2009, August 27.

4. (2010) Humanization of criminal policy of the Republic of Kazakhstan in the light of the concept of legal policy of the Republic of Kazakhstan for since 2010-2020 http://articlekz.com/article/7461

"Kazakhstanskaya Pravda" from 7 of September 2010. - pp.3.

5. (2011) G.Jandagulova «In Kazakhstan in 2011 decriminalization of articles of the Criminal Code of the Republic of Kazakhstan will be carried out that about 12 000 citizens will allow not to be imprisoned.»/ Available: http://newskaz.ru/incidents/20110901/18458 43.html (Accessed: 10.09.2016).

6. (2016) Available: http://kuplu.kz/novosti/?id=1831 (Accessed: 10.09.2016).

7. (2016) Available: http://flashpress.kz/blog/flash/68251.html (Accessed: 10.09.2016).

8. (2016) Available: http://forum.zakon.kz/index.php?/topic/147 424-gumanizatciia-smiagchenie-obratnaiasila-ugolovno/page-15 (Accessed: 10.09.2016) 